\title{
Socio-interactive practices and personality within an EFL online learning environments
}

\author{
Asma Almusharraf ${ }^{1}$ (D) $\cdot$ Norah Almusharraf ${ }^{2}$ (D)
}

Received: 17 November 2020 / Accepted: 21 January 2021/Published online: 8 February 2021

(C) The Author(s), under exclusive licence to Springer Science+Business Media, LLC part of Springer Nature 2021

\begin{abstract}
A primary effort within the literature addresses the needs in acclimatizing dynamic, student-driven instruction to conceive a significantly enhanced online learning environment. This study serves to examine the relationship, if any, between student characteristics (introversion and extraversion) and contribution in the online writing environment (social presence) and their sense of class community in online writing courses. The research was undertaken in a public university in the Kingdom of Saudi Arabia (KSA), examining a sample ( $N=171,36$ males and 135 females) of EFL male and female students. The results confirmed the ICT positive relationships between extraverted and introverted students with their social presence and sense of class community. These results reinforce the instructor's significant role in implementing and engaging students in learning experiences that can address the need for different types of students (e.g., extraverts, introverts) and enhance their interaction through online platforms. The study further calls for developing pedagogically sound approaches to shift away from instructor-fed to student-centered online learning that incorporates instructors' facilitation, constructive and continuous feedback, and clear guidance. It further urges the utilization of sociopsychological methods to address individual differences, especially in online learning.
\end{abstract}

Keywords Computer-mediated communication · Students' characteristics · Introversionextroversion $\cdot$ Social presence $\cdot$ Classroom community

Norah Almusharraf

nmusharraf@psu.edu.sa

Asma Almusharraf

amusharraf@imamu.edu.sa

1 College of Languages and Translation, Al-Imam Mohammad Ibn Saud Islamic University (IMSIU), Riyadh, Saudi Arabia

2 Applied Linguistics Department, College of Humanities, Prince Sultan University, Riyadh, Saudi Arabia 


\section{Introduction}

The latest development of information and communication technology (ICT) has created a surge in demand for online teaching and learning to examine their various formats and platforms in higher and continuing education (Belanger and Jordan 2000; Chou et al. 2019; Moore and Kearsley 1996; Porter et al. 2014), especially during the COVID-19 pandemic, where health circumstances force schools across the world to shift to online learning. Thus, to ensure that high-quality learning is taking place in online learning environments, instructional delivery requires the facilitation of collaborative platforms to promote social presence (Rourke et al. 1999), preparation of interactive activities and resources that foster a sense of community (Rovai 2002a), and careful implementation of technological tools that support learners' characteristics (Ellis 2010).

For the past few decades, researchers and curriculum developers have concentrated on cognitive factors (e.g., learner memory, attention, reasoning, processing, and storing knowledge) and have overlooked other significant factors (e.g., psychological factors) that address an individual's learning differences (Martinez 2001). Psychological factors significantly affect learners' learning style, confidence, and motivation both in face-to-face and online learning environments (Harrington and Loffredo 2010). Students' personality characteristics (e.g., introverted and extroverted) are distinguishable and diverse in their performance (e.g., social presence) of various activities and tasks, including preparation, talking, listening, reflecting, and group or one-on-one meetings (Sun et al. 2020). Further, personality characteristics are significant predictors of learners' achievements and academic performance (Laidra et al. 2007). Neglected, however, are the needs of learners with various personality characteristics, especially introverted learners, which might lead them to be at risk or more inclined to failure in online learning environments (Harrington and Loffredo 2010; Kou et al. 2018; Spark et al. 2018).

Examining learners' sociointeractive practices and personality characteristics within online learning environments is critical to preparing and delivering a quality of teaching instruction (Ahmed et al. 2010). One method of investigating learners' sociointeractive practices is through a determination of their social presence (Rourke et al. 1999), a concept that has been examined to measure online learning experience quality (synchronous or/and asynchronous) and the extent to which a learner acts and perceives the online-mediated communication.

Social presence has been examined in a large number of existing studies in the broader literature of social psychology, collaborative learning, computer-mediated communication (CMC), ICT, online and blended learning, and synchronous and asynchronous learning environments (Allen and Seaman 2011; Hoskins 2012; Hosler and Arend 2012; Lowenthal 2010; Mathieson and Leafman 2014; Rice 1993; Richardson and Swan 2003; Rourke and Anderson 2002; Rourke et al. 1999). Learners' social presence is not only a significantly influential factor of the quality of the online learning environment and learner's perception (Cobb 2009), but it also can contribute to a learner's feelings of a sense of community (Phirangee et al. 2016); for example, through triggering of the feeling of connectedness or disconnection within online learning. Thus, social presence and sense of community are two key constructs that can alleviate feelings of loneliness and connectedness, which some online learners may experience through rapport building, trust, and social reinforcement (Conrad 2005). 
Many studies have been conducted that are related to student personality characteristics of all age groups in various fields (e.g., science, communication, and education) within both academic face-to-face and online learning environments. Some researchers focused on personality characteristics and students' academic performance (e,g., Chesser et al. 2020; Laidra et al. 2007), building and maintaining community (e.g., Conrad 2005; Phirangee et al. 2016), students' perceptions of online learning (e.g., Keller and Karau 2013), and social presence as an individual entity (e.g., Ellis 2010; Simunich and Grincewicz 2018).

However, research on English as a foreign language (EFL) introverted and extroverted learners and social presence in the English language online learning environment remains limited (Garrison 2016; Lee 2013). Furthermore, there are gaps and shortcomings regarding the literature that discusses EFL introverted and extroverted learners' sense of community. Within the Saudi context, there is less previous evidence for research related to EFL learners' attitudes and experiences in online courses (Alghamdi and Holland 2020). This study, therefore, sought to examine EFL learners in a synchronous online platform (Blackboard), during which their interactions were measured through the social presence scale, the students' characteristics were measured through the introversion/ extroversion scale, and the sense of connectedness was determined through the sense of community scale. This study mainly aimed to examine the relationship between students' characteristics (introversion and extroversion) and their collaboration within the online writing environment (social presence). It further explored the relationship between extroverted/introverted learners and their sense of class community in online writing settings. The following are the research questions that underpinned this study:

1. What is the relationship, if any, between introversion/extroversion with respect to social presence and sense of community among undergraduate EFL students within an online writing setting?

2. What is the difference, if any, between introverts and extroverts with respect to their social presence and sense of community?

3. What differences, if any, exist for gender in terms of introversion, social presence, or sense of community?

\section{The literature review}

Extroversion-introversion is intended to assess whether an individual is an extrovert or an introvert. Jung (1971) considered extroversion and introversion as completely contradictory behaviors whose variances create pressure for both the individual and society, if not well-treated. The concept of introversion is sometimes used interchangeably with shyness as a construct, yet it is not equivalent to it (Briggs 1988). Shyness is associated with feelings of discomfort and inhibition or avoidance of normal social behavior in others' presence (Briggs 1988). Introverts are typically introspective and quiet but not necessarily shy.

Extroverts are prepared vitally for social presences and active communications, including analysis and assessment of the learning context (i.e., instructor, classmates, instruction). Introverts are situated primarily within the inner psychological circle, in which their social presence is limited to beliefs about and decisions on ideas and 
thoughts (i.e., acceptance or reluctance). Contrary to extroverts, introverts are not negatively impacted by the lack of interaction with the instructor (Offir et al. 2007) as they prefer "situations that enable solitude and concentration" (p. 14). Generally, introverts prefer to have reasonable alone time, be outside the focus of attention, be in groups of two or three rather than larger groups, be involved in in-depth discussions or task-focused conversation as an alternative to chitchat, have opportunities to reflect before speaking, inquire through questions instead of answering them, and write rather than speak (Jacobs and Renandya 2019). However, Xu and Cooper (2020) argued that, generally, instructors appreciate extroversion in students, including their active involvement in classroom activities and social interaction. $\mathrm{Xu}$ and Cooper asserted that "a student's place on the introversion-extroversion continuum was deemed desirable or undesirable chiefly in terms of the extent to which it led the student to serve the teacher's agenda" (p. 12). Thus, it is critical to understand that these social presence differences should be valued, accepted, and promoted (Mathieson and Leafman 2014).

\subsection{Social presence as a part of the Community of Inquiry (Col) framework}

The concept of social presence was coined in the late 1960s and 1970s during the telecommunication period and was observed as a distant communicative experience. Mehrabian (1968) initiated philosophies of social presence in his idea of immediacy that occurs when individuals act and interact (social behaviors) with each other. Short et al. (1976) viewed social presence as the extent to which participants engage (psychologically [i.e., emotions] and physically [i.e., facial expressions, voice, and tone]) in social communication. Social presence is defined as "the degree of salience of the other person in the interaction and the consequent salience of the interpersonal relationships" (Short et al. 1976, p. 65), and they further viewed social presence as a quality of the communications of individuals' interactions. A more comprehensive description, that can be found within the reviewed studies, is that social presence is the capacity for learners to construct meaning through continuous communication and to connect with a CoI.

The concept of CoI was proposed by Garrison et al. (2000) as a learner's ability to build their social presence through social, physical, and psychological activity in faceto-face or online learning environments. Social presence was initiated before CoI, yet $\mathrm{CoI}$ added a more detailed description to the learning environment, which considers cognitive presence (i.e., inquiry, analysis, and construct meaning) and teaching presence (i.e., plan, facilitate, and direct). Social presence is the extent to which learners have a sense of commitment to the online environment community and develop interpersonal skills (Anderson et al. 2001; Garrison et al. 2000). On the other hand, teaching presence refers to an instructor's approaches that encourage a quality online environment and enable an effective CoI (Bangert 2008). Akyol and Garrison (2008) and Garrison (2016) argued that learners' social presence is directly affected by instructors' teaching presence (i.e., directing the discussion topics, monitoring communication interactions, and facilitating dynamic learning).

Previous research (e.g., Zhao and Sullivan 2017) has investigated the impact of social presence on learners' performance, which revealed that teachers' instructional plans (teaching presence) and direct assistance (social presence) are significantly related to learners' social presence; a higher level of teaching presence is connected with a lower level of student participation, peer communication, cognitive presence, and 
learning contributions. Similarly, Bangert (2008) and Dilling et al. (2020) showed that social presence and teaching presence are vital factors, with the highest cognitive presence levels in the online learning environment, as well as positive constructive and interactive engagement behaviors (Zhang et al. 2016). Thus, for learners to have a social presence and active role in the CoI, the teacher's presence needs to be balanced and directed into recognizing student personality characteristics to maximize learners' contributions within online learning experiences (Rios 2019).

\subsection{Sense of community theory}

The concept of a learner's sense of community within the virtual classroom is present when learners foster community social connection regardless of their physical distance (Rovai 2002a). The instructor's social presence is critical to meditating learners' social presence and community sense. The instructor's role is to design a course that facilitates dialogue and reduces emotional distance, thus cumulating a sense of community among learners. A sense of community is the feeling that members have of social and emotional connection, that they care for one another and the group, and that they have a collective faith that their desires will be met through their commitment to being together (McMillan and Chavis 1986).

Numerous studies (e.g., Chatterjee and Correia 2020; DiRamio and Wolverton 2006; Rovai 2002a, 2002b; Shen et al. 2008) stress the sense of community value in online learning environments. Chatterjee and Correia (2020) used a correlational study to investigate the relationship between students' sense of community and their perceptions toward online collaborative learning and found a positive relationship between collaboration and students' sense of community. Similarly, Dawson (2006) showed that college students who are permitted to be engaged in a high level of communication interactions gain more substantial sense of community levels. By contrast, Cameron et al. (2009) found a limited significant relationship between the different social tasks and students' sense of community, as students were more focused on the group project grade than on developing a sense of community. This finding might reflect the need for clear instructional designs that clearly explain the importance of social connections (building a sense of community) to accomplish a successful group project (Cameron et al. 2009). Table 1 presents the leading indicators of both social presence and sense of community.

Table 1 The Main Indicators of Both Social Presence and Sense of Community

\begin{tabular}{lll}
\hline Elements & Categories & Indicators \\
\hline $\begin{array}{c}\text { Social } \\
\text { Presence }\end{array}$ & $\begin{array}{c}\text { Interactions (group or } \\
\text { individual) } \\
\text { Affective expression } \\
\text { Comse of }\end{array}$ & $\begin{array}{l}\text { Asking questions, expressing agreements or opinions, showing } \\
\text { appreciation, investing in learning }\end{array}$ \\
& & $\begin{array}{l}\text { Feeling of belongings } \\
\text { Shared interests } \\
\text { Shared beliefs }\end{array}$ \\
Accepting & $\begin{array}{l}\text { Contributing to the feeling of obliged commitment } \\
\text { others, }\end{array}$ & \\
& $\begin{array}{l}\text { group and defending } \\
\text { the group, and } \\
\text { showing real identity }\end{array}$ & \\
\hline
\end{tabular}




\subsection{Empirical studies concerning extroverted and introverted learners}

Baradaran and Alavi (2015) examined the discrepancy between extroverted and introverted EFL learners' collaborative writing. They recruited 30 introverted and 30 extroverted Iranian learners as comparison groups under a model of cooperative learning, and the results showed that introverted learners significantly outperform extroverted learners in their writing performance, because they are allowed to write at their own pace using their own expressions, which plays a significant role in decreasing their anxiety level. Several studies (e.g., Boroujeni et al. 2015; Zafar and Meenakshi 2012; Zainuddin 2016) showed agreement with Baradaran and Alavi's (2015) research findings, concluding that introverted learners are more skillful in writing because they use some conceptual strategies (i.e., reflective, attentive, observant, and autonomous) when they write. On the other hand, other studies (e.g., Alavinia and Hassanlou 2014; Qanwal and Ghani 2019) conducted in similar EFL contexts revealed extroversion and introversion have no significant influence on writing proficiency.

Further, previous research (e.g., Alavinia and Hassanlou 2014; Harrington and Loffredo 2010; Hunter 2018; Qanwal and Ghani 2019) explored the relationship between introversion and extroversion communication styles and gender using various tools (e.g., The Myers-Briggs Type Indicator (MBTI) and reported no significant relationships between introverts and extroverts and gender indicating that both extroverts and introverts could be skillful in writing skills. However, as reported by Sun et al. (2020), gender acts as a moderator that affects female students more than males in introversion, which encourages loneliness by aggressive behavior. Hence, a more systematic and theoretical analysis is required to evaluate the effect of instructor presence/instructor control on the relationship between introverted learners and their online writing.

\subsection{Personality differences: Challenges and strategies}

Many factors hold back introverted learners from engaging in learning interactions (Kou et al. 2018; Spark et al. 2018). One of these factors is related to their processing of knowledge of the subject matter because they need more time to process and construct meaning (Rios et al. 2018). Other factors include the instructors' lack of facilitation, direction, and immediate feedback (Rios et al. 2018); lack of engagement tools and engaging content (Davidson et al. 2015); and absence of personalized instruction to meet the students' various needs, skills, and interests (Davidson et al. 2015). Introverted learners' further challenges include unified assessment and evaluation plans, as seen in Davidson et al.'s (2015) argument that introverted learners have higher stress levels than extrovert learners. Further, prior research (e.g., Davidson et al. 2015; Sedova and Navratilova 2020; Zafar and Meenakshi 2012) has provided evidence that introverted learners struggle with functional strategies and social-affective strategies as oral communications. Thus, instructors should plan the evaluation process to include more diverse options that aid in stress reduction, and they should design conceptual strategies that align more with introverted learners.

Prior studies in the literature recommend strategies for introverted learners to overcome the aforementioned challenges. A study by Cheng and Wang (2019) revealed 
that learners using a classroom response system (e.g., clickers) display a stronger motivation to study and enhance academic performance, especially learners who have developed a higher social presence level. Research by Yuliani et al. (2019) suggested using mind mapping techniques to teach writing the narrative text for students with introverted personalities. Further research suggested implementing authentic video materials to facilitate the introverts' and extroverts' learning processes (Isazadeh et al. 2016). Lubis and Rahmawati (2019) proposed using literature circles that include individual responsibility and promotive communication to mediate the implementation of collaborative writing for learners with writing anxiety. Above all, provision of emotional support and personality equity plays a crucial role in the introverted decision-making process (Tao et al. 2020).

In Rios et al.'s (2018) study, the results revealed that extroverted learners are more likely to be gratified with their online learning experience, as determined by the instructor's detailed lesson preparation and direct facilitation, while introverted learners may need further instructor assistance to succeed and be gratified with the course. Positive ideas related to course design reported in Rios, Elliott, and Mandernach's study include user-friendliness, multimodality, accessibility, selfdirectedness, clarity of instructions, constructive feedback, and dynamic collaboration with the instructor and other students. Further, the effective incorporation of multimodal tools (purposeful and meaningful use of technology) positively influences introverted learners' online learning experiences, engagement, and course satisfaction level (Isazadeh et al. 2016; Rios et al. 2018). For instance, instructors could utilize modality through their facilitation of peer or group discussion of a topic of interest by, for example, selecting a movie or educational video for discussion purposes, thereby allowing learners to have room for authority and freedom in selecting complementary technological tools to the lesson.

The current study mainly investigated the relationship and differences between student characteristics (introversion/extroversion) and their collaboration within the online writing environment and their sense of class community in online settings. Also, the differences related to gender in terms of introversion, social presence, or sense of community were further investigated.

\section{Methods}

This survey study investigated the relationship, if existing, between student characteristics (introversion and extroversion) and their contributions (social presence) and sense of class community within the online writing environment. The study's context was within two EFL online synchronous English writing classrooms taught by the same instructor and containing the same subject matter. The course was a third-year course, which included various topics related to literacy writing that require analyzing work-related material and identifying significant aspects of writing genres. Online discussion forums in Blackboard were set up to allow the students to network with each other and provided an opportunity for them to share thoughts in different threads. The study required an instructor who was capable of providing online teaching and had the ability to facilitate interactive learning environments. Therefore, the instructor was purposefully selected because the 
courses' content and the instructor's teaching style (i.e., teaching presence) were prerequisites for the study.

\subsection{Participants}

The study utilized convenience sampling (Cardinal et al. 2015). The participants were ( $N=171,36$ males and 135 females) English-program undergraduate students between the ages of 21-30 from one public university in the KSA. The students were recruited from the same class and program and were at similar levels of EFL proficiency. All students were Saudi EFL learners, and they had passed the school English entrance exam and the foundation year program before being registered into the program. Some students who had scored 5.5 on the IELTS test or 46-59 on the TOEFL were exempted from the English Language foundation year. Thus, it was expected that all the participants' English levels would be suitable for them to understand the surveys' items, which were written in English.

\subsection{Instruments}

Three instruments were used for data collection regarding the participants' degree of introversion/extroversion, social presence, and community sense. To ensure the questionnaires' validity, the researchers distributed the questionnaire to five EFL instructors teaching at a university level. All instructors indicated that the questionnaire statements were clear and suitable for learners.

\subsubsection{Introversion/extroversion scale}

The introversion/extroversion scale was adapted and modified from Richmond and McCroskey (1998). The survey contained 18 Likert-type items that were modified to be suitable and representable within the EFL Saudi context and culture. For example, the idiom "I am usually a good mixer" was changed to "I like to have many social engagements." The introversion/extroversion scale aimed to measure the extent of students' characteristics (extroverted or introverted), and the scoring scale was based on Richmond and McCroskey's scoring method (Richmond and McCroskey 1998). Examples from the survey include "I like to socialize with people" or "I limit my connections to a few selections." Students were asked to select from the following options for each Likert-scale item: Strongly Disagree=1; Disagree 2; Are Undecid$e d=3 ;$ Agree $=4$; Strongly Agree $=5$. The introversion/extroversion scale's potential scores ranged from 18 (pure introversion) to 90 (pure extroversion).

\subsubsection{Social presence scale}

The social presence scale was adapted and modified from Gunawardena and Zittle (1997). Fourteen Likert-type items were listed to examine their extent of online contribution; for example, "I feel comfortable conversing and participating in this text-based medium" and "I feel comfortable introducing myself in the online English course." Students were asked to select from the following options for each item: Strongly Disagree = 1; Disagree 2; Are Undecided=3; Agree=4; Strongly Agree= 5. The potential scores on the social presence scale ranged from 14 to 70 . 


\subsubsection{Sense of community scale}

The social community scale was adapted and modified from (Rovai 2002c) to measure students' sense of community from the beginning to the end of the English course. Fifteen Likert-type items provided an overall sense of community examination consisting mainly of two subscales: connectedness (e.g., "I feel that I can rely on others in this course") and learning (e.g., "I feel reluctant to speak openly"). The potential scores on the sense of community scale ranged from 15 to 75 .

\section{Method}

The survey was created and disseminated using the LimeSurvey online platform. The survey items were explained in advance to ensure students' understanding of each item. The survey's welcome letter stated that completion of the survey denoted the participants' consent to contribute to this research. All students completed the online survey from their laptops or phones using WhatsApp. Participants were given sufficient time to complete the survey to ensure that all items would be answered. The survey was not connected (no control or access over the collected data) with the instructor because one of the researchers distributed the survey links and informed the participants that all collected data were confidential and that all personal data would be de-identified. Participating students were not compensated or given any extra marks for their involvement. For this study, approval from the university's dean and the institutional review board (IRB-2020-07-0049) was obtained as conditional requirements for conducting this research.

\section{Limitations}

The validity of claims made from the analysis of Likery scale data may be affected due to central tendency bias and social response bias.

\subsection{Analysis and results}

This study explored the relationship between student characteristics, their social presence, and their sense of class community within the online writing environment. Responses to each question in the survey were imported from LimeSurvey into SPSS, version 26 for analysis. Table 2 displays the mean, standard deviation, range, skewness,

Table 2 Means, Standard Deviations, Ranges, Skewness, Kurtosis, and Reliability for All Measures

\begin{tabular}{lllllll}
\hline Measure & $M$ & $S D$ & Range & Skewness & Kurtosis & Reliability \\
\hline Introversion/extroversion scale & 57.75 & 6.92 & $34-75$ & -.341 & .955 & .70 \\
Social presence scale & 48.73 & 8.99 & $14-70$ & -1.027 & 2.235 & .87 \\
Sense of community scale & 47.14 & 6.24 & $33-60$ & -.259 & -.698 & .77 \\
\hline
\end{tabular}


kurtosis, and internal consistency reliability (Cronbach's alpha). Skewness is a function of the asymmetry, and kurtosis is a function of a distribution's 'peakedness.' To provide evidence for a normal univariate distribution, any values for skewness between -2 and +2 and for kurtosis between -3 and +3 are considered appropriate (Kim 2013). The skewness was -341 for introversion/extroversion scale, -1.027 for the social presence scale, and -2.59 for the sense of community scale, which indicates significant skewness, according to Kline (2011), but within more relaxed rules set forth by Sposito et al. (1983), who recommend 3.3 as the upper threshold.

The decision was made that, because the introversion/extroversion scale generates scores from 18 to 90, those participants who scored from 18 to 54 would be classified as introverts and those who scored from 55 to 90 would be classified as extroverts. Based on this classification system, $44(25.7 \%)$ and $127(74.3 \%)$ of the participants were classified as introverts and extroverts, respectively. A breakdown of the extroversion versus introversion based on gender shows that $22.2 \%$ (8) of the male participants and $26.7 \%$ (36) of the female participants were identified as introverted and $77.8 \%$ (28) of the male participants, and $73.3 \%$ (99) of the female participants were identified as extroverted.

An independent-samples $t$-test was run to compare gender with respect to introversion/extroversion, social presence, and sense of community. The results of these comparisons, as shown in Table 3, indicate that there were no significant gender differences for introversion/extroversion, social presence, or sense of community among the participants within this study.

A Pearson $r$ correlation coefficient was calculated to determine the relationship between the participants' introversion/extroversion and social presence scores and their introversion/extroversion and sense of community scores. Introversion/extroversion and social presence were found to have a weak positive correlation, $r(171)=.259, p=.001$, while introversion/extroversion and sense of community were found to have a moderate positive correlation, $r(171)=.300, p<.001$. These correlations are depicted as scatterplots for participants' introversion/extroversion and social presence scores (Fig. 1) and participants' introversion/extroversion and sense of community scores (Fig. 2).

Based on their score on the introversion/extroversion scale, participants were categorized as introverts or extroverts. An independent samples $t$-test was run to determine whether there was a difference between introverts and extroverts in terms of their social presence and sense of community. The analyses found that there is a highly significant difference in social presence between introverts and extroverts $t(44)=-3.23, p=.001$ and

Table 3 Comparison between Male and Female Scores for all Measures

\begin{tabular}{lllll}
\hline Measure & Group & $M$ & $S D$ & $t$-test results \\
\hline Introversion/extroversion scale & Male & 59.11 & 7.45 & $t(171)=1.33$, \\
& Female & 57.39 & 6.75 & $p=.184$ \\
Social presence scale & Male & 50.94 & 9.76 & $t(171)=1.67$, \\
& Female & 48.14 & 8.72 & $p=.097$ \\
Sense of community scale & Male & 48.36 & 7.58 & $t(171)=1.33$, \\
& Female & 46.81 & 5.82 & $p=.187$ \\
\hline
\end{tabular}




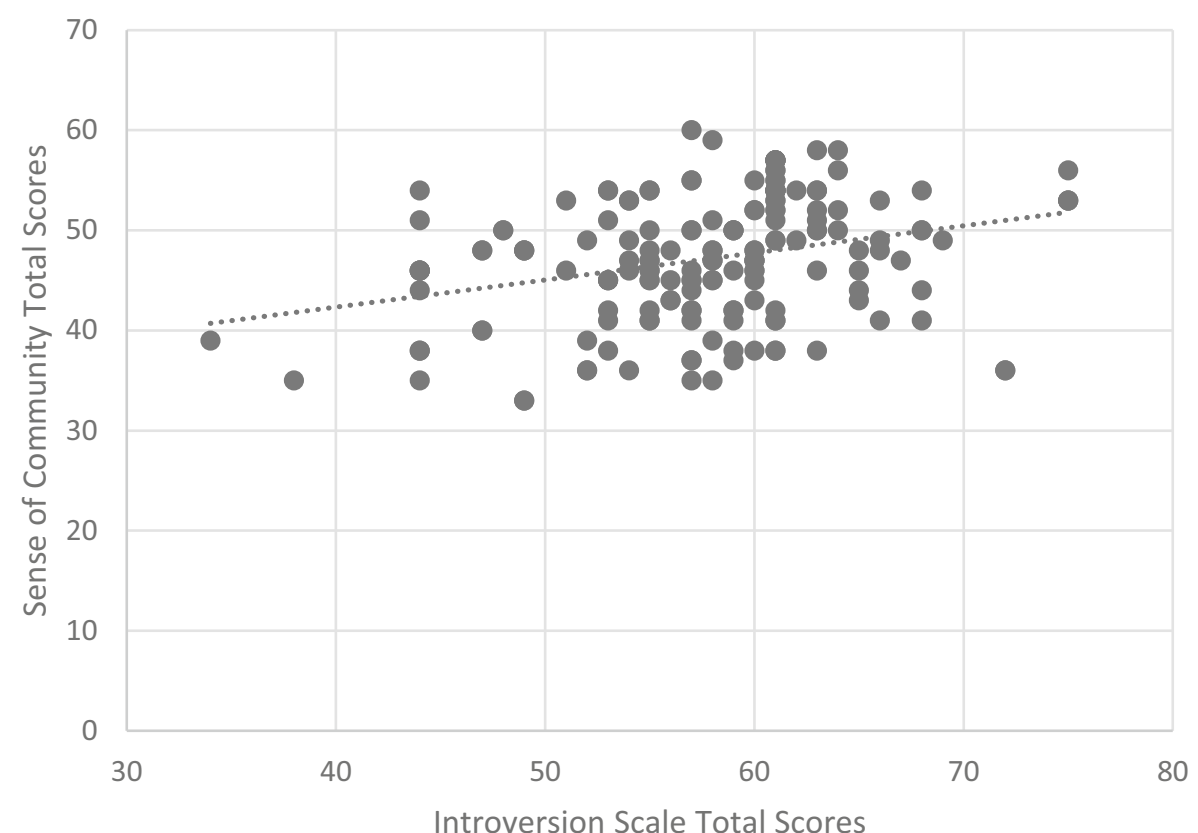

Fig. 1 Scatterplot Depicting Each Participant's Corresponding Introversion/Extroversion and Social Presence Scores

a highly significant difference in sense of community between introverts and extroverts $t(127)=-3.83, p<.001$. Descriptive statistics for the two groups of participants compared to the social presence and sense of community scores are displayed in Table 4.

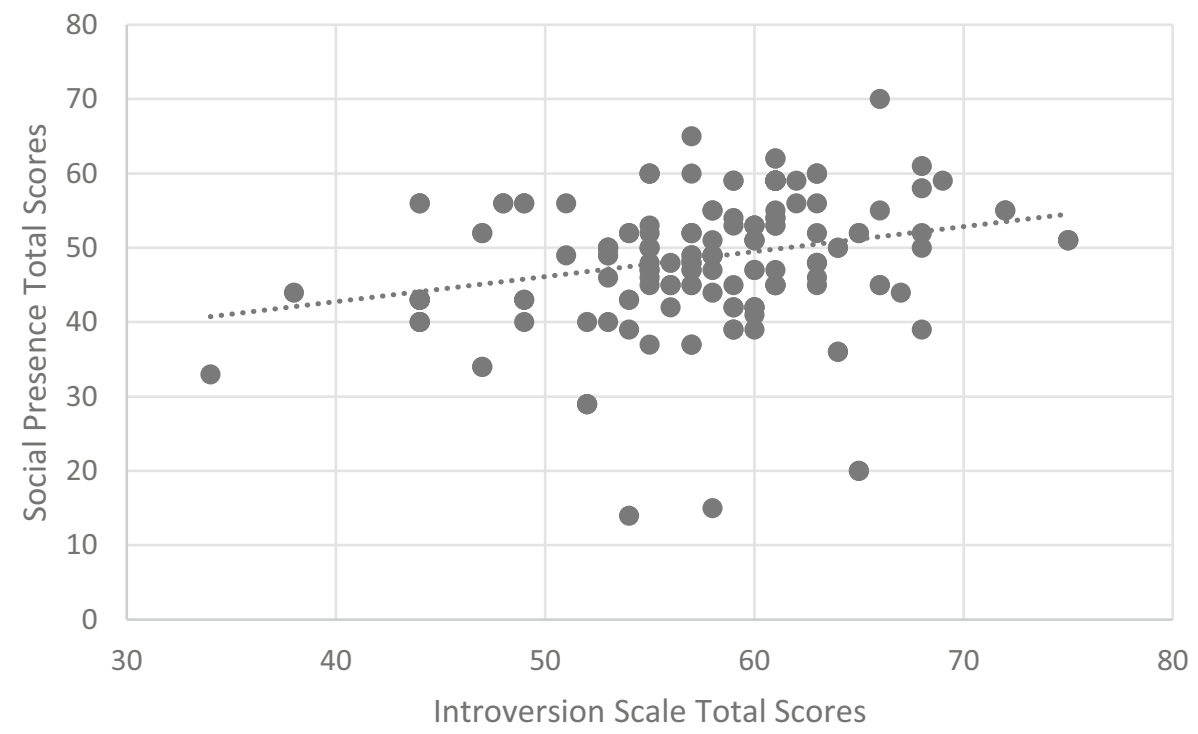

Fig. 2 Scatterplot Depicting Each Participant's Corresponding Introversion/Extroversion and Sense of Community Scores 
Table 4 Means and Standard Deviations for Introverts and Extroverts with Respect to Social Presence and Sense of Community

\begin{tabular}{lllll}
\hline Measure & Group & $n$ & $M$ & $S D$ \\
\hline Social presence scale & Introverts & 44 & 44.43 & 9.07 \\
& Extroverts & 127 & 50.22 & 8.50 \\
Sense of community scale & Introverts & 44 & 44.59 & 6.22 \\
& Extroverts & 127 & 48.02 & 6.02 \\
\hline
\end{tabular}

\section{Discussion}

The study's results have shown that both extroverts and introverts positively correlate with their social presence and sense of class community. The initial focus of the discussion is to answer the first research question, What is the relationship, if any, between introversion/extroversion with respect to social presence and sense of community among undergraduate EFL students within an online writing setting? The study findings revealed that introversion/extroversion and social presence have a weak positive correlation, while introversion/extroversion and sense of community have a moderate positive correlation. The results have explicated that both extroverted and introverted students show a moderate-high sense of class community; they feel connected to the overall classroom community. They denoted membership recognition in the text-based online environment in that they inhabited feelings of friendship, cohesion, and satisfaction. According to Rovai (2002b), once students are accepted as part of a healthy learning community, they develop safety and trust feelings that allow them to speak openly.

These results go beyond previous reports, which showed that the instructor role is essential in promoting students' social presence and their sense of class community. Participants of this study indicated that the instructor promoted a sense of an online community feeling. Instructors need to recognize differences in personal, social, physical, and emotional characteristics of learners' characteristics that vary in online communication (i.e., the extent of comfort levels). Therefore, the findings of this research are in agreement with Akyol and Garrison (2008) and Garrison (2016), who pointed out that students' social presence is directly affected by the instructors' performance, and the findings align with Rios et al.'s (2018) argument that instructors' direct and explicit instruction are the critical factors in facilitating the learning interactions.

Multimodality in delivering the online course instruction is also a significant factor in triggering students' participation. Within this study, participants agreed that discussions using the medium of CMC are not as personal as face-to-face discussions. They further indicated that $\mathrm{CMC}$ video teleconference discussions are more personal than audio and text discussions. Hence, instructors need to plan and continuously evaluate specific technological tools that meet the students' needs. For example, the instructor's social presence within a video conference-based environment is vital to meet up with the students' different needs, including introverts who are coping with the challenges (e.g., anxiety levels that introverts experience trying to accomplish various tasks) of distance learning. Xu and Cooper (2020) argued that "students who were perceived to make 
positive contributions to the teaching and learning environment, and those who presented challenges and difficulties were central to teachers' decision making concerning their expectations of individual students" (p. 16). Therefore, the planning of educational opportunities and teaching resources to be made available within the teaching and learning process is a prerequisite to any successful classroom (Rios et al. 2018).

Previous studies have shown that CMC can be an ideal setting for individuals with difficulty engaging in social communication in the real world (High and Caplan 2009; Ryan and Xenos 2011); however, it is not the medium but rather how one uses the medium that makes the difference (Clark 1994). The instructors' awareness of the effect of learners' personality traits on their social presence and classroom community should be fully considered. Therefore, it has been argued that inclusive education includes an appreciation of diversity in many forms, including personality differences (e.g., extroversion-introversion) and enforcing emotional support (Jacobs and Renandya 2019; Tao et al. 2020). Further, introverted students should not be looked at as disadvantaged learners; instead, they should be included and appreciated as "careful listeners, detailed observers, and reflective thinkers" (Jacobs and Renandya 2019, p. 81) that can add a rich and advanced layer to the learning experience for students and instructors. While the current study did not measure the instructor's social presence, the findings from students' perceptions regarding their need for instructor guidance support the notion that the instructor influences the classroom interactions; thus, it can be claimed that instructor facilitation is crucial in promoting students' social presence and their sense of class community.

The next focus of the discussion is to answer the second research question, What is the difference, if any, between introverts and extroverts with respect to their social presence and sense of community? The present study confirmed predictable findings of the existing relationship between introverts and extroverts and their social presence and their sense of community in online writing courses. This study's results show that there is a highly significant difference in social presence between introverts and extroverts and a highly significant difference in the sense of community between introverts and extroverts. This result is in line with previous research, which indicates that extroverts are active in communicating, asking questions, and collaborating with others ( $\mathrm{Xu}$ and Cooper 2020). Extroverts generally seek fulfillment from sources outside themselves. According to previous research, getting energy from outside sources is referred to as externalizing and environment-shaping, representing one of the main characteristics of extroverts (Dewaele and Furnham 1999).

Further, participation behavior as an expression of a student's individual characteristics might be a consequence of the interplay between the student and that student's social environment (Sedova and Navratilova 2020). Thus, instructors should pay more attention to the construction of the student participation in the classroom, focusing on students with different personalities who participate in whole-class talk to a limited extent. On the other hand, introverts do not generally get much involved in social interaction, limiting their connection to a few selections, and they feel nervous when asking questions or working with a group. However, even though the results revealed a higher extent of social presence and sense of class community with respect to extroverts, introverts positively correlated with both social presence and sense of class community. There is a strong argument supporting the belief that CMC (e.g., Blackboard) provides a better medium for social and classroom interactions than face-to-face interaction (Kehrwald 2008). A similar pattern of results was obtained in this study in which introverts expressed, within the introversion/ 
extroversion scale, that they were able to overcome feelings of loneliness or isolation, and both extroverts and introverts showed a substantial social presence in the text-based learning environment and felt comfortable participating and collaborating in course discussion. This result agrees with some previous studies (e.g., Boroujeni et al. 2015; Zafar and Meenakshi 2012; Zainuddin 2016), arguing that introverted learners are more skillful in writing because they use some conceptual strategies (i.e., reflective, attentive, observant, and autonomous) when they write.

It is critical to note that the learning subscale within the classroom community scale did not measure perceived learning; it only examined learners' feelings about the classroom community's ability to help them feel valued and connected with the instructor and other students in the class. This study showed that the EFL environment aided in enhancing students' desire to acquire knowledge and allowed the participants ample opportunities to learn. A similar conclusion was reached by Hrastinski (2009), who stated that "participation and learning are argued to be inseparable and jointly constituting. That is, if we want to enhance online learning, we need to enhance online learner participation" (p. 78). Likewise, Dawson (2006) indicated that students involved in a high level of communication interaction gain more substantial levels of community sense.

Overall, because the examined context is situated within EFL writing classes and because, as Oxford (1990) suggested, language is a form of social behavior, language learning also has to be connected to communication between and among individuals to enrich their language output. Oz (2014) indicated that because extroverts possess characteristics such as sociability, talkativeness, and friendliness, they are generally expected to be good second language learners. Therefore, it is believed that good language learners can control their emotions about learning (Oxford 1990) as negative feelings in the learning environment can stunt language learning progress. The current study showed that introverts and extroverts are able to control some of their negative feelings (e.g., tense, nervous, anxious, not comfortable) while communicating in the online text-based classes. Therefore, as Mathieson and Leafman (2014) and Rios (2019) indicated, students' personalities need to be recognized and equally directed by the instructor to allow them to have a social presence. For example, the instructor could identify introverts from the first orientation of the class and encourage them to overcome negative feelings that inhibit online class communication by participating in a risk-free and low-effective environment.

The last focus of the discussion is to answer the third research question, What differences, if any, exist for gender in terms of introversion, social presence, or sense of community? The independent-samples $t$-test indicated no significant gender differences for introversion/extroversion, social presence, or sense of community among the participants within this study. This result is consistent with prior research (e.g., Alavinia and Hassanlou 2014; Harrington and Loffredo 2010; Hunter 2018; Qanwal and Ghani 2019) indicating that both extroverts and introverts could be skillful in their writing skills, and their findings revealed no significant relationships between introverts and extroverts and gender. It is important to note here that there is very little research related to gender differences in online settings. Although male- and female-typical behaviors in face-to-face interaction are well documented in the literature, there is still a lack of research examining gender differences among introverted and extroverted learners in computer-mediated communication. 


\section{Conclusion}

This study makes a significant contribution by highlighting the need for instructors to be aware of learners' social personalities, thereby impacting their learning performance and engagement in online settings. This work presents interesting results pertaining to the importance of establishing a social presence and sense of community amongst extrovert and introvert learners within online learning settings. Findings from the study indicate that extrovert learners benefit the most during online learning because their inquisitive and outgoing personality are influential factors in determining the success of the learning process.

As has been argued elsewhere here, the instructor's presence is positively associated with students' social presence and classroom community, and the findings of this study may be considered a promising aspect of rethinking online classroom instructional practices. This study confirmed positive relationships between extroverts and introverts, and their social presence and sense of class community necessitate further validation and replication in studies where broader contexts are taken into consideration. The study results also reinforce the instructor's significant role in implementing and engaging students in learning experiences that can address the needs of different types of students (e.g., extroverts, introverts) and enhance their online platform interaction. The broad implication of the present research is that it is valuable to instructors, instructional designers, and policymakers, in light of the understanding of learners' different characteristics and personalities, because it allows them to develop interactive online courses and continuously examine students' needs and challenges to increase their engagement in online courses, including other factors that can establish a good social interactivity and collaboration based on individual learning styles and preferences. The issue discussed in the study is current, which should significantly help other researchers in a similar field when embarking on similar research.

There are several limitations to this study. First, the results cannot be generalized for all students, because they only relate to a relatively small population in a specific EFL context. The learner characteristics, course design, and pedagogy used by the online instructor in the present study may not be fully representative of other EFL learning contexts. The study participants were also only involved in using one synchronous online platform (Blackboard); therefore, the study results may not generalize to other online platforms. Further, only quantitative instruments were applied in this research; the students' characteristics were measured through the introversion/extroversion scale, their interactions were measured through the social presence scale, and their sense of connectedness and learning was determined through the community scale. Along with quantitative measures, qualitative instruments (e.g., class observations, one-to-one, and group interviews, students' artifacts) could be implemented in future research to enrich and validate the current results' output. Regardless, future research could continue to explore more research that applies and tests online learning activities that might be remedial approaches to specific learners.

Looking forward, further attempts and further recommendations may be considered a promising aspect of EFL online writing courses. The current results warrant further investigation via creating introvert-friendly opportunities to encourage students to write dialogue journals in which they record their thoughts and experiences in an informal manner (Jacobs and Renandya 2019). Further studies should investigate using CRS in 
write responses (Cheng and Wang 2019), literature circles in online cooperative writing for learners with writing anxiety (Lubis and Rahmawati 2019), and authentic multimodal implementations (Isazadeh et al. 2016). On this basis, it can be concluded that this study adds to the research literature in understanding the nature of the relationship between introverts and extroverts and their social presence and sense of connectedness within the online writing environment. Future research is still needed to develop further and confirm these findings of students' characteristics within online EFL settings.

With the COVID-19 pandemic still present, which heavily impacts the education landscape, the need for a stronger sense of online committee is more urgent, and learners' social presence is one of the utmost essential elements to be considered in any online learning setting. Further research is also required in examining larger multicultural samples and different online platforms before any definitive conclusion can be made regarding the relationship of students' characteristics, social presence, and sense of classroom community. The paper concludes by arguing that more research is needed to identify different pedagogical approaches to develop learners' social presence and promote higher levels of sense of community.

Acknowledgments The Researcher Thanks Prince Sultan University for Funding This Research Project Under Grant [Applied Linguistics Research [Lab- RL-CH-2021/1].

Declarations Research involving human participants and/or animals

Informed consent A contest was obtained in the welcoming letter of the digital survey.

Conflict of interest No conflict of interest.

\section{References}

Ahmed, F., Campbell, P., Jaffar, A., Alkobaisi, S., \& Campbell, J. (2010). Learning \& personality types: A case study of a software design course. Journal of Information Technology Education: Innovations in Practice, 9, 237-252. https://doi.org/10.28945/1329.

Akyol, Z., \& Garrison, D. R. (2008). The development of a community of inquiry over time in an online course: Understanding the progression and integration of social, cognitive and teaching presence. Journal of Asynchronous Learning Networks, 12(3), 3-22 https://files.eric.ed.gov/fulltext/EJ837483.pdf.

Alavinia, P., \& Hassanlou, A. (2014). On the viable linkages between extroversion/introversion and academic Iranian EFL learners' writing proficiency. English Language Teaching, 7(3), 167-175. https://doi.org/10. 5539/elt.v7n3p167.

Alghamdi, J., \& Holland, C. (2020). A comparative analysis of policies, strategies and programmes for information and communication technology integration in education in the Kingdom of Saudi Arabia and the Republic of Ireland. Education and Information Technologies, 25, 4721-4745. https://doi.org/10. 1007/s10639-020-10169-5.

Allen, I, E., \& Seaman, J. (2011). Going the distance: Online education in the United States, 2011. Sloan Consortium. https://www.onlinelearningsurvey.com/reports/goingthedistance.pdf

Anderson, T., Rourke, L., Garrison, D. R., \& Archer, A. (2001). Assessing teaching presence in a computer conferencing context. Journal of Asynchronous Learning Networks, 5(2), 1-17 https://auspace. athabascau.ca/bitstream/handle/2149/725/assessing_teaching_presence.pdf?sequence=1\&isAllowed=y.

Bangert, A. (2008). The influence of social presence and teaching presence on the quality of online critical inquiry. Journal of Computing in Higher Education, 20(1), 34-61. https://doi.org/10.1007/bf03033431.

Baradaran, A., \& Alavi, M. (2015). The difference between extrovert/introvert EFL learners' cooperative writing. International Journal of Language Learning and Applied Linguistics World, 8(2), 13-24 http:// citeseerx.ist.psu.edu/viewdoc/download?doi=10.1.1.678.4550\&rep=rep1\&type=pdf. 
Belanger, F., \& Jordan, D, H. (2000). Distance learning technologies. IGI Global. https://doi.org/10.4018/9781-878289-63-6.ch003.

Boroujeni, A. J., Roohani, A., \& Hasanimanesh, A. (2015). The impact of extroversion and introversion personality types on EFL learners' writing ability. Theory and Practice in Language Studies, 5(1), 212218. https://doi.org/10.17507/tpls.0501.29.

Briggs, S. R. (1988). Shyness: Introversion or neuroticism? Journal of Research in Personality, 22(3), 290307. https://doi.org/10.1016/0092-6566(88)90031-1.

Cameron, B. A., Morgan, K., Williams, K. C., \& Kostelecky, K. L. (2009). Group projects: Student perceptions of the relationship between social tasks and a sense of community in online group work. American Journal of Distance Education, 23(1), 20-33. https://doi.org/10.1080/08923640802664466.

Cardinal, P., Zamora, M. C., Chambers IV, E., Carbonell Barrachina, Á., \& Hough, G. (2015). Convenience sampling for acceptability and CATA measurements may provide inaccurate results: A case study with fruit-flavored powdered beverages tested in Argentina, Spain and USA. Journal of Sensory Studies, 30(4), 295-304. https://doi.org/10.1111/joss.12158.

Chatterjee, R., \& Correia, A. P. (2020). Online students' attitudes toward collaborative learning and sense of community. American Journal of Distance Education, 34(1), 53-68. https://doi.org/10.1080/08923647. 2020.1703479 .

Cheng, L. T., \& Wang, J. W. (2019). Enhancing learning performance through classroom response systems: The effect of knowledge type and social presence. The International Journal of Management Education, 17(1), 103-118. https://doi.org/10.1016/j.ijme.2019.01.001.

Chesser, S., Murrah, W., \& Forbes, S. A. (2020). Impact of personality on choice of instructional delivery and students' performance. American Journal of Distance Education, 34, 211-223. https://doi.org/10.1080/ 08923647.2019.1705116.

Chou, C. M., Shen, C. H., Hsiao, H. C., \& Shen, T. C. (2019). Factors influencing teachers' innovative teaching behaviour with information and communication technology (ICT): The mediator role of organisational innovation climate. Educational Psychology, 39(1), 65-85. https://doi.org/10.1080/ 01443410.2018.1520201.

Clark, R. E. (1994). Media will never influence learning. Educational Technology Research and Development, 42(2), 21-29. https://doi.org/10.1007/BF02299088.

Cobb, S, C. (2009). Social presence and online learning: A current view from a research perspective. Journal of Interactive Online Learning, 8(3). https://www.ncolr.org/jiol/issues/pdf/8.3.4.pdf

Conrad, D. (2005). Building and maintaining community in cohort-based online learning. International Journal of E-Learning \& Distance Education/Revue internationale du e-learning et la formation à distance, 20(1), 1-20 https://pdfs.semanticscholar.org/d3b2/65ca01aa9b175d70d8038bd5e0dcf28748c1. pdf.

Davidson, B., Gillies, R. A., \& Pelletier, A. L. (2015). Introversion and medical student education: Challenges for both students and educators. Teaching and Learning in Medicine, 27(1), 99-104. https://doi.org/10. 1080/10401334.2014.979183.

Dawson, S. (2006). A study of the relationship between student communication interaction and sense of community. The Internet and Higher Education, 9(3), 153-162. https://doi.org/10.1016/j.iheduc.2006.06. 007.

Dewaele, J. M., \& Furnham, A. (1999). Extraversion: The unloved variable in applied linguistic research. Language Learning, 49(3), 509-544. https://doi.org/10.1111/0023-8333.00098.

Dilling, J., Varga, M. A., \& Mandernach, B. J. (2020). Comparing teaching and social presence in traditional and online community college learning environments. Community College Journal of Research and Practice, 44(10-12), 854-869. https://doi.org/10.1080/10668926.2020.1752852.

DiRamio, D., \& Wolverton, M. (2006). Integrating learning communities and distance education: Possibility or pipedream? Innovative Higher Education, 31(2), 99-113. https://doi.org/10.1007/s10755-006-9011-y.

Ellis, A. (2010). Personality type and participation in networked learning environments. Educational Media International, 40(1-2), 101-114. https://doi.org/10.1080/0952398032000092152.

Garrison, D, R. (2016). E-learning in the 21st century: A community of inquiry framework for research and practice (3rd ed.). Routledge. https://doi.org/10.4324/9781315667263.

Garrison, D. R., Anderson, T., \& Archer, W. (2000). Critical inquiry in a text-based environment: Computer conferencing in higher education. The Internet and Higher Education, 2(2-3), 87-105. https://doi.org/10. 1016/S1096-7516(00)00016-6.

Gunawardena, C. N., \& Zittle, F. J. (1997). Social presence as a predictor of satisfaction within a computermediated conferencing environment. American Journal of Distance Education, 11(3), 8-26. https://doi. org/10.1080/0892364970952697. 
Harrington, R., \& Loffredo, D. A. (2010). MBTI personality type and other factors that relate to preference for online versus face-to-face instruction. The Internet and Higher Education, 13(1-2), 89-95. https://doi.org/ 10.1016/j.iheduc.2009.11.006.

High, A. C., \& Caplan, S. E. (2009). Social anxiety and computer-mediated communication during initial interactions: Implications for the hyperpersonal perspective. Computers in Human Behavior, 25(2), 475482. https://doi.org/10.1016/j.chb.2008.10.011.

Hoskins, B. J. (2012). Connections, engagement, and presence. The Journal of Continuing Higher Education, 60(1), 51-53. https://doi.org/10.1080/07377363.2012.650573.

Hosler, K. A., \& Arend, B. D. (2012). The importance of course design, feedback, and facilitation: Student perceptions of the relationship between teaching presence and cognitive presence. Educational Media International, 49(3), 217-229. https://doi.org/10.1080/09523987.2012.738014.

Hrastinski, S. (2009). A theory of online learning as online participation. Computers \& Education, 52(1), 7882. https://doi.org/10.1016/j.compedu.2008.06.009.

Hunter, E. H. (2018). An examination of how gender may relate to communication styles of introversion and extroversion in nursing students. Nursing Education Perspectives, 39(4), 233-234. https://doi.org/10. 1097/01.NEP.0000000000000270.

Isazadeh, P., Makui, S. M. Z., \& Ansarian, L. (2016). Effect of instructional vs. authentic video materials on introvert and extrovert Iranian EFL learners' vocabulary learning. International Journal of Education and Literacy., 4(4), 1-10. https://doi.org/10.7575/aiac.ijels.v.4n.4p.1.

Jacobs, G. M., \& Renandya, W. A. (2019). Student centered cooperative learning: Linking concepts in education to promote student learning. Berlin: Springer.

Jung, C. G. (1971). Personality types. The portable Jung, 178-272.

Kehrwald, B. (2008). Understanding social presence in text-based online learning environments. Distance Education, 29(1), 89-106. https://doi.org/10.1080/01587910802004860.

Keller, H., \& Karau, S. J. (2013). The importance of personality in students' perceptions of the online learning experience. Computers in Human Behavior, 29(6), 2494-2500. https://doi.org/10.1016/j.chb.2013.06. 007.

Kim, H. Y. (2013). Statistical notes for clinical researchers: Assessing normal distribution using skewness and kurtosis. Restorative Dentistry \& Endodontics, 38(1), 52-54. https://doi.org/10.5395/rde.2013.38.1.52.

Kline, R. B. (2011). Principles and practice of structural equation modeling (3. Bask1). New York, NY: Guilford. Chicago.

Kou, S., McClelland, A., \& Furnham, A. (2018). The effect of background music and noise on the cognitive test performance of Chinese introverts and extraverts. Psychology of Music, 46(1), 125-135. https://doi. org/10.1177/0305735617704300.

Laidra, K., Pullmann, H., \& Allik, J. (2007). Personality and intelligence as predictors of academic achievement: A cross-sectional study from elementary to secondary school. Personality and Individual Differences, 42(3), 441-451. https://doi.org/10.1016/j.paid.2006.08.001.

Lee, S. M. (2013). The relationships between higher-order thinking skills, cognitive density, and social presence in online learning. The Internet and Higher Education, 21, 41-52. https://doi.org/10.1016/j. iheduc.2013.12.002.

Lowenthal, P. R. (2010). Social presence. In Social computing: Concepts, methodologies, tools, and applications (pp. 129-136). Pennsylvania: IGI global.

Lubis, A. H., \& Rahmawati, E. (2019). Literature-circles-based cooperative writing: From the perceptions of Indonesian university EFL learners with writing anxiety. Journal of AsiaTEFL, 16(4), 1422-1431. https:// doi.org/10.18823/asiatefl.2019.16.4.26.1422.

Martinez, M. (2001). Key design considerations for personalized learning on the web. Journal of Educational Technology \& Society, 4(1), 26-40 https://www.jstor.org/stable/jeductechsoci.4.1.26.

Mathieson, K., \& Leafman, J, S. (2014). Comparison of student and instructor perceptions of social presence. Journal of Educators Online, 11(2). https://doi.org/10.9743/jeo.2014.2.3.

McMillan, D. W., \& Chavis, D. M. (1986). Sense of community: A definition and theory. Journal of Community Psychology, 14(1), 6-23. https://doi.org/10.1002/1520-6629(198601)14:1<6::AIDJCOP2290140103>3.0.CO;2-I.

Mehrabian, A. (1968). Some referents and measures of nonverbal behavior. Behavior Research Methods \& Instrumentation, 1(6), 203-207. https://doi.org/10.3758/bf03208096.

Moore, M. G., \& Kearsley, G. G. (1996). Distance education: A system view. (No. C10 20). Wadsworth.

Offir, B., Bezalel, R., \& Barth, I. (2007). Introverts, extroverts, and achievement in a distance learning environment. The American Journal of Distance Education, 21(1), 3-19. https://doi.org/10.1080/ 08923640701298613. 
Oxford, R. L. (1990). Research on second language learning strategies. Annual Review of Applied Linguistics, 13, 174-187.

$\mathrm{Oz}, \mathrm{H}$. (2014). Big five personality traits and willingness to communicate among foreign language learners in Turkey. Social Behaviour \& Personality: An International Journal, 42(9), 1473-1482. https://doi.org/10. 2224/sbp.2014.42.9.1473.

Phirangee, K., Epp, C. D., \& Hewitt, J. (2016). Exploring the relationships between facilitation methods, students' sense of community, and their online behaviors. Online Learning, 20(2), 134-154. https://doi. org/10.24059/olj.v20i2.775.

Porter, W. W., Graham, C. R., Spring, K. A., \& Welch, K. R. (2014). Blended learning in higher education: Institutional adoption and implementation. Computers \& Education, 75, 185-195. https://doi.org/10. 1016/j.compedu.2014.02.011.

Qanwal, S., \& Ghani, M. (2019). Relationship between introversion/extroversion personality trait and proficiency in ESL writing skills. International Journal of English Linguistics, 9(4), 107-114. https:// doi.org/10.5539/ijel.v9n4p107.

Rice, R. E. (1993). Media appropriateness: Using social presence theory to compare traditional and new media. Human Communication Research, 19(4), 451-484. https://doi.org/10.1111/j.1468-2958.1993. tb00309.x.

Richardson, J., \& Swan, K. (2003). Examining social presence in online courses in relation to students' perceived learning and satisfaction. Journal of Asynchronous Learning Networks, 7(1), 68-88. https://doi. org/10.24059/olj.v7i1.1864.

Richmond, V, P., \& McCroskey, J, C. (1998). Communication apprehension, avoidance and effectiveness (5th ed.). Allyn \& Bacon. http://www.as.wvu.edu/ richmond/measures/introversion.pdf

Rios, T. (2019). The relationship between students' personalities and their perception of online course experiences. Journal of Educators Online, 16(1). https://doi.org/10.9743/jeo.2019.16.1.11.

Rios, T., Elliott, M., \& Mandernach, B. J. (2018). Efficient instructional strategies for maximizing online student satisfaction. Journal of Educators Online, 15(3). https://doi.org/10.9743/jeo.2018.15.3.7.

Rourke, L., \& Anderson, T. (2002). Exploring social communication in asynchronous, text-based computer conferencing. Journal of Interactive Learning Research, 13(3), 259-275 https://www.learntechlib.org/p/ $15133 /$.

Rourke, L., Anderson, T., Garrison, D., \& Archer, W. (1999). Assessing social presence in asynchronous textbased computer conferencing. The Journal of Distance Education/Revue de L'education Distance, 14(2), 50-71 https://core.ac.uk/download/pdf/58774853.pdf.

Rovai, A, P. (2002a). Building sense of community at a distance. The International Review of Research in Open and Distance Learning, 3(1). https://doi.org/10.19173/irrodl.v3i1.79.

Rovai, A. P. (2002b). Sense of community, perceived cognitive learning, and persistence in asynchronous learning networks. The Internet and Higher Education, 5(4), 319-332. https://doi.org/10.1016/s10967516(02)00130-6.

Rovai, A. P. (2002c). Development of an instrument to measure classroom community. Internet and Higher Education, 5(3), 197-211. https://doi.org/10.1016/S1096-7516(02)00102-1.

Ryan, T., \& Xenos, S. (2011). Who uses Facebook? An investigation into the relationship between the big five, shyness, narcissism, loneliness, and facebook usage. Computers in Human Behavior, 27(5), 16581664. https://doi.org/10.1016/j.chb.2011.02.004.

Sedova, K., \& Navratilova, J. (2020). Silent students and the patterns of their participation in classroom talk. Journal of the Learning Sciences, 29(4-5), 681-716. https://doi.org/10.1080/10508406.2020.1794878.

Shen, D., Nuankhieo, P., Huang, X., Amelung, C., \& Laffey, J. (2008). Using social network analysis to understand the sense of community in an online learning environment. Journal of Educational Computing Research, 39(1), 17-36. https://doi.org/10.2190/ec.39.1.b.

Short, J., Williams, E., \& Christie, B. (1976). The social psychology of telecommunications. Toronto; London; New York: Wiley.

Simunich, B., \& Grincewicz, A. M. (2018). Social presence and cultural identity: Exploring culturally responsive instructional design in the online environment. In Cultivating diverse online classrooms through effective instructional design (pp. 136-162). Pennsylvania: IGI Global.

Sposito, V. A., Hand, M. L., \& Skarpness, B. (1983). On the efficiency of using the sample kurtosis in selecting optimal lpestimators. Communications in Statistics-simulation and Computation, 12(3), 265272.

Spark, A., Stansmore, T., \& O'Connor, P. (2018). The failure of introverts to emerge as leaders: The role of forecasted affect. Personality and Individual Differences, 121, 84-88. https://doi.org/10.1016/j.paid.2017. 09.026 . 
Sun, L., Fu, Z., \& Zheng, Y. (2020). Shyness and loneliness in Chinese young adults: Roles of aggression and gender. Journal of Aggression, Maltreatment \& Trauma. Advance online publication. https://doi.org/10. 1080/10926771.2020.1725209.

Tao, Y., Cai, Y., Rana, C., \& Zhong, Y. (2020). The impact of the extraversion-introversion personality traits and emotions in a moral decision-making task. Personality and Individual Differences, 158, 109840. https://doi.org/10.1016/j.paid.2020.109840.

Xu, S, Q., \& Cooper, P. (2020). Mainstream teachers' perceptions of individual differences among students in inclusive education settings of China. International Journal of Inclusive Education. Advance online publication. https://doi.org/10.1080/13603116.2020.1735541, 1, 19.

Yuliani, W., Bharati, D. A. L., \& Warsono, W. (2019). The effectiveness of brainstorming and mind mapping to teach writing narrative text for students with extrovert and introvert personalities. English Education Journal, 9(4), 459-466. https://doi.org/10.15294/eej.v9i4.32098.

Zafar, S., \& Meenakshi, K. (2012). A study on the relationship between extroversion-introversion and risktaking in the context of second language acquisition. International Journal of Research Studies in Language Learning, 1(1), 33-40. https://doi.org/10.5861/ijrs11.2012.v1i1.42.

Zainuddin, Z. (2016). The impact of personality: Extrovert vs. introvert on the ability in syntax in essay writing. Studies in English Language and Education, 3(2), 158-169. https://doi.org/10.24815/siele.v3i2. 4963.

Zhang, H., Lin, L., Zhan, Y., \& Ren, Y. (2016). The impact of teaching presence on online engagement behaviors. Journal of Educational Computing Research, 54(7), 887-900 https://eric.ed.gov/?id= EJ1117923.

Zhao, H., \& Sullivan, K. P. (2017). Teaching presence in computer conferencing learning environments: Effects on interaction, cognition and learning uptake. British Journal of Educational Technology, 48(2), 538-551. https://doi.org/10.1111/bjet.12383.

Publisher's note Springer Nature remains neutral with regard to jurisdictional claims in published maps and institutional affiliations.

Dr. Asma Almusharraf is an assistant professor at Al Imam Mohammad Ibn Saud Islamic University (IMSIU), Saudi Arabia. She gained her Ph.D. in applied linguistics with the first degree of honor. Her research interest includes Language Acquisition, Foreign Language Teaching and Learning, Computer-Assisted Language Learning and Professional Development.

Dr. Norah Almusharraf is an assistant professor, Applied Linguistics Department, College of Humanities, Prince Sultan University, Riyadh, Saudi Arabia. She holds a Ph.D. in Foreign and Second language Education from the University at Buffalo. Her professional and research interests focus on English as a foreign language (EFL) learning pedagogics, inquiry-based teaching and learning, project-based learning and content-based instruction, cultural magnitudes of foreign/s language teaching and learning classroom, multimodal assessment and teaching strategies, technology implantation in the EFL English classrooms, teacher professional development using class critique and through professional learning community (PLC), qualitative research methods: dialogic classroom discourse \& comparative case studies, and computing implementations in statistical research. 